\section{Experimental Production of Green and Colourless Hydra.}

W GOETSCH, of Munich, has carried out a series of experiments on Hydra, and has published the results in some half-dozen short papers, two of which form the subject of this notice (Die Naturerissenschaften, pp. 202-205, 867-87I, I922). Specimens of Hydra are either green, brown, or grey, and these are regarded by most authors as belonging to distinct species or even genera, though in certain cases the brown and grey are difficult to distinguish. Goetsch points out that the brown and green may also be difficult to distinguish, for some of the former can take green algæ into their endoderm cells and form a symbiotic union similar to that long known in green Hydra.

Goetsch obtained from a warmed tank in the Botanic Garden in Nymphenburg some brown Hydra which showed pathological features, and when he fed these with algæ they developed a green colour first around the mouth, then in the foot region, and finally in the intervening portion, so that in about a fortnight the entire animal had an intense green colour. The spread of the algæ was accompanied by a progressive diminution in the size of the Hydras so that they had difficulty in capturing their prey, the reserve material of the interstitial cells degenerated, and budding ceased. These green examples disappeared from the aquarium, but a few which remained in culture vessels were fed with freshly killed Daphnia and were thus carried through their abnormal condition. The reciprocal toleration between the Hydra and the alga soon becomes an intimate association. Afterwards these Hydra produced buds containing the green algæ, and some of them showed ovaries or testes-apparently two were males and two were females.

It is impossible to determine whether the specimens are $H$. attenuata or $H$. vulgaris. The alga in these green specimens is (as in the true green Chlorohydra) a Chlorella, but differs from that in Chlorohydra in being twice as large, and in being situated in the distal end of the endoderm cells, whereas in Chlorohydra the algæ are near the base of the endoderm cells. These green examples differ further from Chlorohydra in that the symbiosis is easily lost; if the green specimens are kept in the dark or cold the green colour disappears with the exception of a small amount around the base of the tentacles, but on transferring the specimens to better conditions the algæ begin to multiply again. Specimens kept four weeks in darkness lost every trace of their alga ; the only way to make these green again was to introduce into them fresh algæ contained in crushed pieces of green specimens enclosed in the carapace of a Daphnia.

Goetsch suggests that this brown Hydra is a new mutant, and that with the origin of this mutant capable of receiving the algæ in the warm house in the Botanic Garden the conditions were for the first time favourable for the institution of the symbiosis. This union cannot be maintained through the cold of winter, and is not transmitted through the egg. In Nature the Hydras would probably not have come through the first attack by the algæ, for those in the cultures owed their survival to artificial help. If a brown and a green specimen of the same species be cut into two and a brown piece and a green piece be joined together by means of a hair, there is a gradual extension of the algæ into the previously uninfected part.

The problem of the production of colourless specimens from the green Chlorohydra has also been attacked by Goetsch. Colourless examples were obtained by Whitney by placing Chlorohydra in weak glycerine, which caused the endoderm cells to expel their algæ. Hadzi kept Chlorohydra in the dark and they produced eggs without algæ, and he thus obtained alga-free examples one of which was reared. Goetsch kept Chlorohydra under unfavourable conditions-cold, darkness, and lack of calciumto suppress the growth of the algæ, and then liberally fed the Hydra so that their cells multiplied so quickly that the algæ could not keep pace. After a few weeks of such treatment the buds produced were of a paler colour, especially in the middle region of the body. As this is the region where asexual reproduction takes place, offspring were eventually obtained free from algæ. These whitish specimens are more feeble than green examples, and require careful treatment. A spontaneous return of colour in these white specimens has not occurred, although some of them have lived for four months in the light.

Deep green and colourless pieces were joined together and the spread of the green alga was studied. Algæ thrust out of the endoderm cells of the green part are taken up with other food by the endoderm cells of the other part, so that after a few days the whitish part begins to exhibit a green colour, even at places distant from the junction. If a bud is formed at the junction of the two pieces it may be half green and half white. Such a bud affords strong evidence against the purely ectodermal origin of buds.

\section{University and Educational Intelligence.}

ABERDEEN.-At the spring graduation held on March 28, Sir George Adam Smith, the vice-chancellor, presiding, the degree of LL.D., honoris causa, was conferred on Sir William H. Beveridge, director of the London School of Economics; Dr. E. W. Hobson, Sadleirian professor of pure mathematics, University of Cambridge ; Dr. W. Mackie, of Elgin, distinguished by his researches on the geology of the north-east, of Scotland; Sir George H. Makin, consulting surgeon to St. Thomas's Hospital; and Prof. C. Niven, emeritusprofessor of natural philosophy, University of Aberdeen.

The degree of Doctor of Science (D.Sc.) has been conferred on Dr. J. L. Rosedale for a thesis- "On the Hydrolysis of the Proteins of Flesh."

The Senatus Academicus has appointed Prof. Matthew Hay to represent the University at the Pasteur centenary celebrations to be held in Paris and Strasbourg in May.

Prof. Kruyt, Utrecht University,. will deliver a university lecture in the faculty of science on May I I.

Durham.--Prof. H. Louis, at present professor of mining and surveying, and William Cochrane lecturer in metallurgy at Armstrong College, will vacate his appointments on September 30, 1923, on reaching the retiring age. Prof. G. Poole, of the University of Leeds, has been appointed as professor of mining. This appointment was made by the council on the recommendation of a joint committee of the College and the Durham and Northumberland Coal Trades Association. Dr. J. A. Smythe, at present senior lecturer in chemistry, will take over the William Cochrane lectureship in metallurgy; other arrangements are being made in connexion with the surveying teaching, formerly under the supervision of Prof. Louis.

Prof. R. F. A. Hoernlé, professor of philosophy, has now left England to take up his appointment as professor of philosophy in the University of Johannesburg. The council of Armstrong College will proceed. 
to the appointment of a successor to take up office in October.

Prof. G. H. Thomson, professor of education, and joint author with Dr. William Brown of the "Essentials of Mental Measurement," has been invited by the Teachers' College, Columbia University, New York, to spend next academic year there, delivering advanced courses on psychology. The council of Armstrong College has granted him a year's leave for this purpose.

London.-Presentation Day will be held in the Royal Albert Hall, on Thursday, May 3.

The degree of D.Sc. in biochemistry has been conferred on Miss K. H. Coward, an internal student, of University College, for a thesis entitled "The Formation of Vitamin A in Plant Tissues."

Applications are invited for the Astor chair of pure mathematics tenable at University College, in succession to Prof. M. J. M. Hill, retired. The latest date for the receipt of applications, by the Academic Registrar, University of London, South Kensington, S.W.7 (I2 from each candidate) is May 24.

Manchester.-The trustees of the Dickinson scholarships, open to medical students and graduates of the University, have announced the conditions and regulations. The scholarships are as follows: (i.) research travelling scholarship in medicine, of the value of 3 ool. for one year, awarded annually; the scholar is required to spend at least ten months abroad and undertake there original investigation; (ii.) anatomy scholarship ( $25 l$. for one year), to be awarded to the most distinguished first-year anatomy student; (iii.) surgery scholarship ( $75 l$. for one year, offered in alternate years to a scholarship in pathology), open to medical graduates of the University; the scholar must devote himself to original investigation; and (iv.) pathology scholarship ( $75 l$. for one year), on the same lines as the surgery scholarship. Full particulars are to be obtained from Mr. Frank G. Hazell, Secretary to the Dickinson Trustees, The Royal Infirmary, Manchester.

OXFORD.-A fund amounting to nearly $2000 l$. has been raised to provide a memorial of the late Sir William Osler, Regius professor of medicine. It has been decided to place a memorial bronze plaque in the University Museum, and to award a medal every five years to a graduate of the University who has made some distinguished contribution to medical science. It is also desired to provide a fund to assist teachers in the University to travel for purposes connected with medical knowledge and research. For this latter object further contributions are required; these should be sent to Mr. A. P. Dodds-Parker, 2 Holywell, Oxford.

The professor of pathology, Dr. G. Dreyer, has been appointed to represent the University at the forthcoming celebration at Paris and Strasbourg of the centenary of the birth of Pasteur.

Mr. M. E. Shaw; of New College, has been elected Radcliffe travelling fellow. The Radcliffe prize has been awarded to Dr. A. D. Gardner, University College, sometime Radcliffe travelling fellow.

The Matteucci gold medal, conferred as a posthumous honour by the International Research Council at Brussels in I9I9 on the late Mr. H. G. Moseley, of Trinity College, has been received at Oxford and delivered to his mother, Mrs. Sollas.

The governing body of Exeter College will hold an election in the summer term to a research fellowship of $200 l$. a year, free of income tax, tenable for 5 years. Candidates, who must be members of the University of Oxford of at least B.A. standing, must send in applications by May I 5 to the rector, who will supply further details.

$$
\text { NO. } 2788 \text {, VOL. I I I] }
$$

\section{Societies and Academies.}

\section{LONDON.}

Geological Society, February I6.-Prof. A.C. Seward, president, in the chair.-A. C. Seward: The earlier records of plant-life (presidential address). Reference was made to the views of Dr. Church on the origin of life in the waters of a primeval world-ocean, and on the origin of terrestrial vegetation from highlyorganised Algæ transferred by emergence of portions of the earth's crust above the surface of the water. The vegetation of the land may have received additions from upraised portions of the crust at more than one epoch in the history of the earth. The course of evolution is probably more correctly illustrated by the conception of separate lines of development, than by that of a branching tree implying the common origin of the main groups of plants. The unfolding of plant-life must be considered in relation to the changing geological background. Diffusionphenomena, as illustrated by the so-called Liesegang figures, possibly explain the origin of some of the structures which are usually attributed to organic agency. We have no knowledge of any Pre-Cambrian land-flora. The phyla of Lycopods and Ferns are regarded as independently-evolved groups. The wide geographical range of Archæopteris was emphasised, and reference was made to the difficult problems raised by the occurrence of Upper Devonian floras well within the Arctic circle, at least equal (in the variety of the plants and in the vigorous development of the vegetation) to the more southern floras of Ireland, Belgium, and other regions.

March I4.--Prof. A. C. Seward, president, in the chair.-E. M. Anderson: The geology of the schists of the Schichallion district of Perthshire. Between Carn Mairg and Schichallion the succession is:-graphiteschist: pebbly quartzite: mica-schist: non-pebbly quartzite : schichallion boulder-bed. Following the boulder-bed, and thus on the same side of the quartzite, are a white limestone, a banded series of siliceous and micaceous rocks, a grey carbonacèous limestone, and a slightly carbonaceous mica-schist, which may be named the grey schist. On approach to the white limestone the boulder-bed becomes highly calcareous. This conglomerate is probably a tillite, and has been partly formed from the material of the limestone. There may thus be a chronological sequence, of which the oldest visible member is the grey schist, extending upwards to the Ben Ledi grits in an adjoining part of Perthshire. In the northern part of the Schichallion district the Dalradian series is bordered by the Struan flags. The junction is probably not an unconformity, but either a normal fault which has been affected by strong horizontal movement, or else a folded thrust.-H. H. Read: The petrology of the Arnage district in Aberdeenshire: a study of assimilation. The modification of magmas by the incorporation of material of sedimentary origin is here termed contamination. In the Arnage mass in Aberdeenshire the sediments concerned in contamination are : (a) andalusite-schists and pebbly grits of the Fyvie series; and $(b)$ biotite-schists and subordinate hornblende-schists of the Ellon series. The contaminated rocks occur as a roof-zone, some hundreds of feet thick, overlying a sheet of norite rich in magnesia, and are of four types. Assuming that the initial magma was normal gabbro, the contamination-process depends on reciprocal reaction between initial magma and xenoliths, whereby the magma loses magnesia and lime and becomes richer in alumina and alkalies, the final results of the reciprocal reaction being the granitic Ardlethen 